"Generational links between entrepreneurship, management and puritanism"

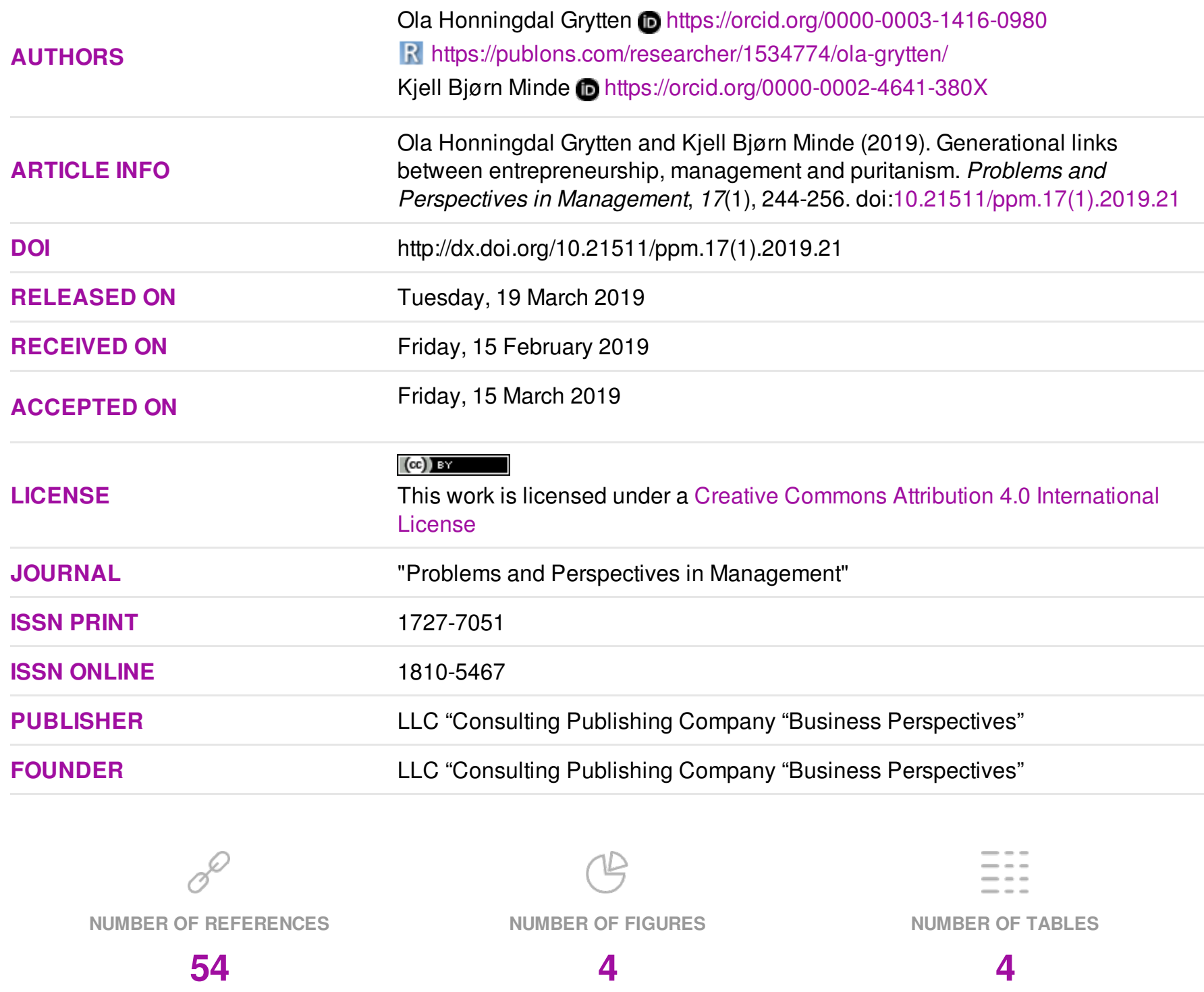

(C) The author(s) 2022. This publication is an open access article. 


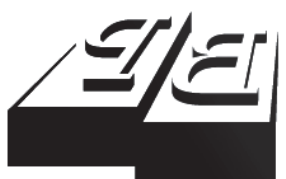

BUSINESS PERSPECTIVES

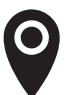

LLC "CPC "Business Perspectives" Hryhorii Skovoroda lane, 10, Sumy, 40022, Ukraine

www.businessperspectives.org

Received on: $15^{\text {th }}$ of February, 2019 Accepted on: $15^{\text {th }}$ of March, 2019

(C) Ola Honningdal Grytten, Kjell Bjørn Minde, 2019

Ola Honningdal Grytten, Professor Dr Oecon, Department of Economics, Norwegian School of Economics, Norway.

Kjell Bjørn Minde, Dr Oecon Associate Professor, Department of Pedagogy, Religion and Social Studies, Western Norway University of Applied Science, Norway.

\section{(c) (i)}

This is an Open Access article, distributed under the terms of the Creative Commons Attribution 4.0 International license, which permits unrestricted re-use, distribution, and reproduction in any medium, provided the original work is properly cited.

\title{
GENERATIONAL LINKS BETWEEN ENTREPRENEURSHIP, MANAGEMENT AND PURITANISM
}

\begin{abstract}
This paper deals with relationships between puritanism, management and entrepreneurship. As this is an on-going debate among economic historians, it focuses on the period from the early 1800 s until present times, where Norwegian high profile puritan entrepreneurship serves as the case.

The theoretical framework is that entrepreneurship is seen as an important liaison factor representing multifactor productivity in a Solow growth model. The paper provides new insight within different areas on the basis of utilization of available sources. Firstly, it gives new estimates of the entrepreneurship of the puritan leader, Hans Nielsen Hauge (1771-1824).

Secondly, it organizes his followers in three generations. The first is those who directly took up his heritage, i.e. Haugeans. Their heydays lasted until the middle of the 19th century. The second generation is characterized as Haugean descendants. These were highly influenced by the movement's values. They dominated the scene from the late 1800 s to the late 1900 s. The third generation is called Neo-Haugeans, largely a fruit of the revival of Haugean values during the last decades.

Thirdly, the paper maps attributes and motivation of this puritan entrepreneurship during generations. The authors conclude that it was guided by high degree of innovation, family ownership, wide portfolios, and continuity, when stewardship seems to be an important motivational factor.
\end{abstract}

\section{Keywords}

\section{JEL Classification $\quad$ M13, M14, N13, N14, O12, O31}

\section{INTRODUCTION}

During the 1800s, Norway for its first time experienced continuous economic growth. One of the central entrepreneurs in the early 19th century was the lay preacher Hans Nielsen Hauge (1771-1824). Along with his followers, Hauge strongly contributed to modernize industrial activity and society at large (Kullerud, 1996, pp. 8-13).

They emphasized puritan values, like Christian stewardship, hard work and individual responsibility. This inspiration contributed to a diversity of industrial activities. Hauge can be characterized as an industrial, social, political and religious reformator. Additionally, he promoted women's right to participate in the public arena (Haukland, 2014a, pp. 326-339). He was also considered a threat to the establishment (Ravnåsen, 2002).

His movement's ideas were central elements in the formation of the modern state, local democracy, parliamentarism, equal rights, common rule of law, and market liberalism (Haukland, 2014b, pp. 539-559). They were sceptical to central governance, public spending, exclusive privileges and political and religious enforcement systems (Sjursen, 1997). 


\section{PROBLEM DEFINED}

On the theoretical basis of the Solow growth model an available data as departure, the present paper seeks to focus on three central issues connected to the industrialism of the puritan movement.

In the first place, it offers a new quantitative assessment of Hauge's industrial and financial engagements. Secondly, it organizes his followers into three generations or waves of entrepreneurship. Thirdly, it seeks to map characteristic attributes of industrial management of these three generations.

\section{THEORETICAL FRAMEWORK}

\subsection{Solow growth model}

Growth accounting divides economic growth into two parts. The first part can be attributed to the production factors, including labor and capital, natural resources. The second part is multifactor productivity (MFP), which consists of qualitative factors such as technology, institutions, frameworks, and composition of inputs and organization of production. Thus, production can be stated as function of capital $C$, labor $L$ and multifactor productivity $A$ in a certain period $t$ :

$$
Y_{t}=A_{t} F\left(C_{t}, L_{t}\right)
$$

The input factors' share of contribution to production can be expressed as in equation 2 :

$$
Y_{t}=A_{t}+\alpha C_{t}+(1-\alpha) L_{t}
$$

Economic growth can be expressed arithmetically as growth in $Y$ as consequence of growth in $C$, $L$, and $A$, where $\alpha$ denotes share of input contribution to production (Denison, 1967, pp. 278-300):

$$
\frac{\Delta Y_{t}}{Y_{t}}=\frac{\Delta A_{t}}{A_{t}}+\alpha \frac{\Delta C_{t}}{C_{t}}+(1-\alpha) \frac{\Delta L_{t}}{L_{t}} .
$$

Thus, long-term economic growth is explained by increase in production capacity. The ability to produce decides the production possibility frontier (Solow, 1956, pp. 65-94). Empirical research concludes that MFP is the most important factor for growth. In other words, the efficiency in the composition and utilization of capital and labor is the most important growth factor (Abramowitz, 1956, pp. 5-23).

\subsection{Protestant ethics and economic growth}

This paper focuses on one of the features of MFP, i.e. entrepreneurial activity. An entrepreneur connects innovation, labor, capital and markets into new business (Schumpeter, 1939, pp. 41-53). It is difficult to account for the contribution of entrepreneurship to economic growth. However, empirical research confirms its importance, when historical research confirms a link between puritanism and entrepreneurship (McCleary, 2006, pp. 49-72; Young, 2009).

Weber (1905) gave his interpretation on the possible historical linkage between protestant ethics and economic growth. Weber described what he called "the capitalist spirit", which to a large degree developed from protestant ethics of duty and calling. His theory on the linkage between protestant ethics, entrepreneurship and economic growth is illustrated in Figure 1.

Weber argued that protestant directions, an in particular the puritan movements, were more individualistic in their approach to religion than Catholicism and Orthodoxism. Each individual was made responsible to God and for his or her own salvation; one could neither go via a church nor any rites, but through individual relationship

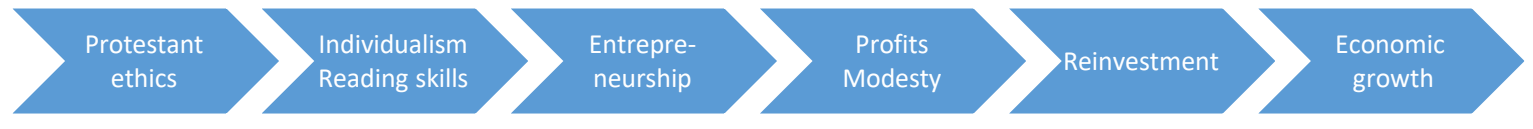

Figure 1. Weber's algorithm on link between protestant ethics and economic growth 
with God himself. This also influenced moral perceptions. According to Weber, protestant moral attitudes promoted hard work, moderate consumption and individual responsibility.

Protestants also had an individual responsibility to read the Bible. Thus, they set up compulsory schools, and reading skills became superior to everybody else. Individualism, high saving rates due to moderate consumption and reading skills paved the way for entrepreneurship. As a result, profits were reinvested rather than consumed with economic growth. Weber saw the same kind of reasoning within Catholicism and Orthodoxism. However, it was not as widespread and more confined to monasteries: "The puritan wanted to work in calling ... For when asceticism was carried out of monastic cells into everyday life, and began to dominate worldly morality, it did its part in building the tremendous cosmos of the modern economic order. This order is now bound to the technical and economic conditions of machine production, which today determine the lives of all the individuals who are born into this mechanism, not only those directly concerned with economic acquisition, with irresistible force. Perhaps it will so determine them until the last ton of fossilized coal is burnt" (Weber, 1905).

Puritans in the UK and USA were pioneers within the establishment of industry, labor welfare, democracy, human rights and social justice. Recent research has confirmed that they were significantly more likely to pioneer industry during the 18th and 19th century (Emden, 1939; Jeremy, 1988; Iannaconne, 1998; Bremer, 2005).

Lutheran pietists in Germany represented a similar mentality. In France, one finds the entrepreneurship of the Huguenots. In Switzerland, the Netherlands and Scotland, the Calvinists put extra emphasis on ethics of calling. In Norway, one could find an aristocracy of pietists among the hanseatic merchants in Bergen (Kaelber, 2005).

International historical research has chiefly concluded that different directions of protestant ethics, basically represented by puritan movements, have motivated economic, political, social and educational entrepreneurship (Barro, 2003). However, the results are still under debate (Delacroix, 2001).
The link is not evident in Western economies at present times, but it can arguably be seen in developing economies (McCleary, 2006; Young, 2009).

\section{DATA AND PREVIOUS WORK}

In order to conduct the present study, we need to draw on information from several sources. The most important source for the pioneer time of the movement is a doctoral thesis by Breistein (1953). The aim of the thesis was to do research into the legal process against Hauge on the basis of claims of fraud. In order to do so, Breistein compiled data from business accounts, correspondence and legal negotiation. Rødal and Kiplesund (2009) re-organized this material in order to map financial transactions.

On the basis of their research, one may conclude that Hauge was engaged directly or indirectly in about 150 industrial or business engagements from 1799 until his death in 1824. In at least 75 of these, he contributed as banker or investor. Most of the engagements were small-scale regarding turnover and labor force. Some had just a handful employees, when the largest should be regarded large-scale in the early 1800 s. If one assumes an average labor force of 20 in his more than 30 manufacturing plants, that would account for 600 . If we assume 15 on average for all kinds of business he was directly or indirectly involved in, we reach at 2.250 .

Another source would be Hodne's (1999) compilation of data in order to estimate the size of value added for Norwegian manufacturing for the late 1820s. As he also maps Haugean establishments, it enables one to map some of the first generation entrepreneurship and industrialism. According to this work, one may estimate the labor force of Haugean production units within manufacturing, crafts and construction to about 7,000-8,000 around 1828 (Hodne, 1999, pp. 41-61). However, these numbers are far from precise.

In order to map second generation Haugeans, we use established business history and local history literature for the period covering the late 1800s to the late 1900s. This literature is huge in volumes and 


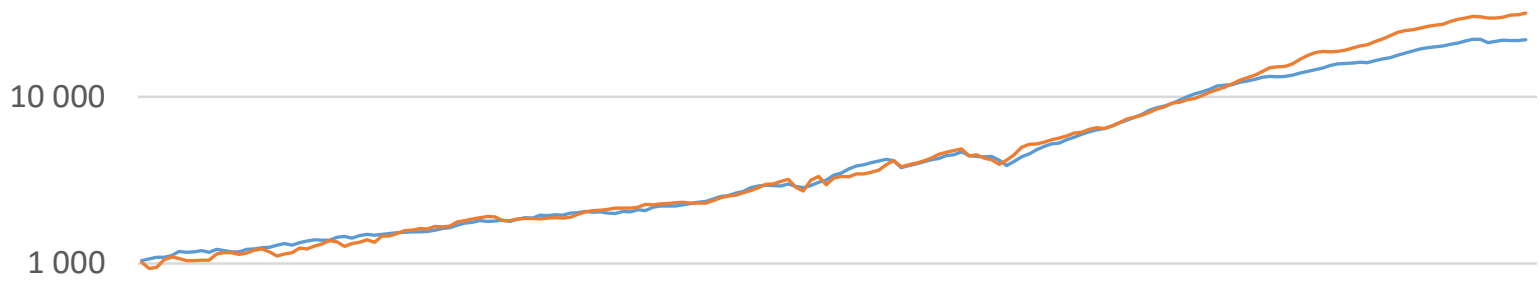

100

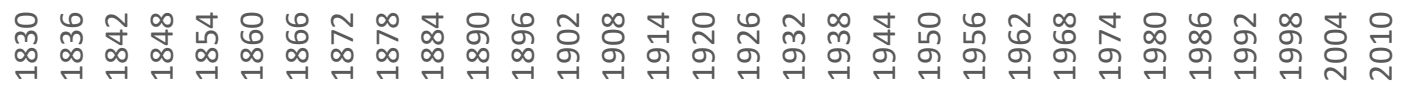

Figure 2. GDP per capita in Western Europe (blue) and Norway (red) for 1830-2015 in 2002, US\$

contains considerable information on the group we are investigating into. Unfortunately, with few exceptions, little has been done in order to organize these works quantitatively (Jonasson, 1946).

Third generation Haugeans are mapped through more recent business history literature, research and recent interviews. This literature enables us to quantify the material in different ways by compiling data from these various sources (Grytten, 2013, pp. 31-44).

\section{ECONOMIC GROWTH}

Jonasson (1946) concluded that Haugean entrepreneurship was significantly correlated with waves of economic growth, where growth lagged by some years to entrepreneurship. Figure 2 reveals substantial economic growth from the 1830s, the heydays of first generation Haugeans. One then finds a new wave of economic growth after a second wave of Haugean inspired entrepreneurship both in the early 1900s and in the second half of the 1930s. The birth of aquaculture in the 1970s was influenced by Neo-Haugean entrepreneurship.

We also find that Norwegian growth rates were higher than those of Western Europe in total until the 1870s. A new similar wave came from the 1970s after the discovery of oil and gas on the continental shelf. Figure 3 describes Norwegian GDP per capita compared to Western Europe, one of the wealthiest parts of the world. Norway was a relatively wealthy country as early as the 1800 s, basically due to high productivity levels and utilization of natural resources (Hodne, 1981).

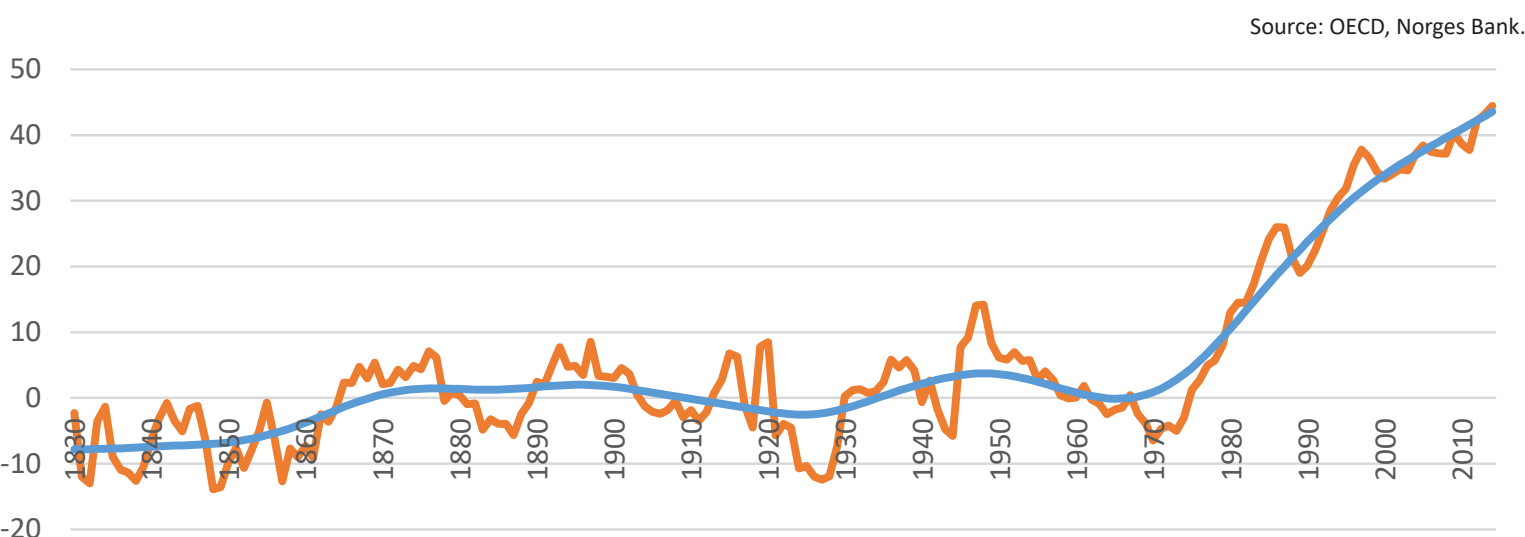

Notes: Red line - annual differences in percent. Blue line - smoothed annual differences by HP filter (lambda $=100)$.

Figure 3. Norwegian GDP per capita relative to Western Europe for 1830-2015 in 2002, US\$ 
Table 1. Portfolio of Hauge's engagement

Source: Breistein (1953, pp. 104-159), Rødal and Kiplesund (2009, pp. 18-44).

\begin{tabular}{|c|c|c|c|c|c|}
\hline $\begin{array}{l}\text { Agriculture, } \\
\text { forestry and } \\
\text { fisheries }\end{array}$ & $\begin{array}{c}\text { Manufacturing, } \\
\text { crafts and } \\
\text { construction }\end{array}$ & Services & Political & Religious & Welfare and education \\
\hline $\begin{array}{l}\text { - Agriculture } \\
\text { - Cattle breeding } \\
\text { - Forestry } \\
\text { - Fisheries } \\
\text { - Fish processing }\end{array}$ & $\begin{array}{l}\text { - Manufacturing } \\
\text { - Innovation } \\
\text { - Shipyard } \\
\text { - Entrepreneurship } \\
\text { - Publishing } \\
\text { - Distilleries } \\
\text { - Mining } \\
\text { - Brick making }\end{array}$ & $\begin{array}{l}\text { - } \text { Trade } \\
\text { - } \text { Property } \\
\text { - Ship owner } \\
\text { - } \text { Shipping services } \\
\text { - } \text { Banking } \\
\text { - Journalism } \\
\text { - Editorial work }\end{array}$ & $\begin{array}{l}\text { - Political } \\
\text { influence } \\
\text { - Popular } \\
\text { movement } \\
\text { - Electorate } \\
\text { enlightment }\end{array}$ & $\begin{array}{l}\text { - Preaching } \\
\text { - Reformation } \\
\text { - Authorship } \\
\text { - Editorial } \\
\text { - Revivalist }\end{array}$ & $\begin{array}{l}\text { - Popular enlightenment } \\
\text { - Social reformism } \\
\text { - Teaching } \\
\text { - Labor welfare } \\
\text { - Business education } \\
\text { - Schooling } \\
\text { - } \text { Bechnical enlightment } \\
\end{array}$ \\
\hline
\end{tabular}

\section{HAUGE'S} ENTREPRENEURSHIP

\subsection{Motivation}

Hauge's break through can be dated to the years 1796-1804. He seldom aimed at personal profits and his spending was modest. His motivation seems to have been what he considered God given calling to stewardship. Being modest and working hard were both Christian duties and pleasure. Profits should be reinvested in order to give jobs to needy and hard working people: "not to live abundantly and collect wealth for one selves, but to please others and share ones earnings, more or less to the benefit of others..."1.

People should be equipped to manage on their own, which would give the largest welfare surplus. Hauge considered industrial activities as part of a spiritual ministry: You know with me, that we are not placed in the world in order to consume alone, not to enjoy and amuse ourselves, ... rather we should deny this ... neither spend the gifts of God on the Evil and Cheep, the Over-Spender and Lazy, those who can never have enough, Coveters, who want to consume from others work, who demand a lot from the work of others, but never have any desire of doing something good for others..."2.

\subsection{Business areas}

In 1801, Hauge gained privileges as merchant in Bergen, one of the most important economic cities in Scandinavia at the time. The local bishop pro- tected him against the government in Copenhagen, Denmark. Thus, Bergen became his base until he was arrested in October 24, 1804 outside the city of Drammen. Gaining privileges became a ramp for further involvement in business and manufacturing (Breistein, 1953, pp. 75-93).

Even in arrest Hauge established companies and production plants. By going through a rich material of sources, one can conclude that he set up or restarted at least 30 manufacturing establishments. In addition, he was heavy involved as investor, banker or consultant in an even higher number of establishments. His participation in different areas of activities is listed in Table 1.

\subsection{Finance activities}

By organizing the data compiled by Breistein and Rødal, and Kiplesund (2009) it is possible to give estimates of Hauge's basic financial transactions. His by far most active year was 1804 , when we find 36 large financial transactions. To arrive at relevant estimates of these, we have inflated them by the inverse of the implicit deflator of gross investments according to the historical national accounts ${ }^{3}$. One then arrives at the transaction value in 2018 Norwegian kroner (TNOK2018):

$$
\text { TNOK } 2018=T_{t}^{n}=T_{t} \cdot \frac{P_{n}}{P_{t}}=T_{t} \cdot\left(\frac{I_{n}^{c}}{I_{n}^{f}} / \frac{I_{t}^{c}}{I_{t}^{f}}\right)
$$

where $T_{t}^{n}$ denotes transaction, $T$ in period $t$, measured in values of period $n$, when $P_{n}$ denotes the price level, $P$, of period $n$, and $P_{t}$ is the price level, $P$, of period $t$. $I$ denotes gross investments

\footnotetext{
Letter from Hans Nielsen Hauge, dated 02.09.1816.

Letter from Hans Nielsen Hauge, dated 05.03.1815.

https://www.norges-bank.no/en/Statistics/Historical-monetary-statistics/Gross-domestic-product/
} 
according to the national accounts, when $c$ denotes current prices and $f$ fixed prices in period $t$ and $n$, where $t=1,804$ and $n=2,018$.

However, this measure does not take into account the increase of purchasing power. We can include this factor by calculating annual wage equivalents. This is done by dividing the amount of the transactions with the average wage of 1,804 , which is computed to have been 80 riksdaler. Next one multiplies this factor by present wages, $W_{t}$ arrives at a sum showing the value of the financial transactions in 2018 wages, $W_{n}$ which in total shows the value of the transaction measured in average 2018 wages (TAWNOK2018) ${ }^{4}$ :

$T A W N O K 2018=T_{t}^{n}=\frac{T_{t}}{W_{t}} \cdot W_{n}=T_{t} \cdot \frac{W_{n}}{W_{t}}$.

Table 2 reports Hauge's investment and financing activities in his most active year, 1804. The transactions were carried out in riksdaler (RD), and converted to kroner (NOK) according to conversion tables from the central bank $\mathrm{k}^{5}$. The sums reveal substantial financial activity, which made him an important investor at the time.

Table 2. Transactions by Hauge in 1804 , in NOK

Source: Breistein (1953, pp. 75-159), Hodne (1999, pp. 41-61), Rødal and Kiplesund (2009, pp. 84-87).

\begin{tabular}{|c|c|c|c|c|c|c|c|}
\hline \multicolumn{4}{|c|}{ Payments } & \multicolumn{4}{|c|}{ Investments } \\
\hline RD & TNOK2018 & $\mathrm{AW}$ & TAWNOK2018 & RD & TNOK2018 & $\mathrm{AW}$ & TAWNOK2018 \\
\hline 6,200 & $5,655,733$ & 77.5 & $42,470,000$ & 1,800 & $1,641,987$ & 22.5 & $12,330,000$ \\
\hline 335 & 305,592 & 4.2 & $2,294,750$ & 1,500 & $1,368,322$ & 18.8 & $10,275,000$ \\
\hline 15 & 13,683 & 0.2 & 102,750 & 300 & 273,664 & 3.8 & $2,055,000$ \\
\hline 12,000 & $10,946,580$ & 150.0 & $82,200,000$ & 5,800 & $5,290,847$ & 72.5 & $39,730,000$ \\
\hline 2,800 & $2,554,202$ & 35.0 & $19,180,000$ & 50 & 45,611 & 0.6 & 342,500 \\
\hline \multirow[t]{30}{*}{450} & 410,497 & 5.6 & $3,082,500$ & 900 & 820,993 & 11.3 & $6,165,000$ \\
\hline & & & & 900 & 820,993 & 11.3 & $6,165,000$ \\
\hline & & & & 10,000 & $9,122,150$ & 125.0 & $68,500,000$ \\
\hline & & & & 2,000 & $1,824,430$ & 25.0 & $13,700,000$ \\
\hline & & & & 772 & 704,230 & 9.7 & $5,288,200$ \\
\hline & & & & 800 & 729,772 & 10.0 & $5,480,000$ \\
\hline & & & & 1,315 & $1,199,563$ & 16.4 & $9,007,750$ \\
\hline & & & & 230 & 209,809 & 2.9 & $1,575,500$ \\
\hline & & & & 100 & 91,221 & 1.3 & 685,000 \\
\hline & & & & 200 & 182,443 & 2.5 & $1,370,000$ \\
\hline & & & & 150 & 136,832 & 1.9 & $1,027,500$ \\
\hline & & & & 3,200 & $2,919,088$ & 40.0 & $21,920,000$ \\
\hline & & & & 234 & 213,458 & 2.9 & $1,602,900$ \\
\hline & & & & 100 & 91,221 & 1.3 & 685,000 \\
\hline & & & & 200 & 182,443 & 2.5 & $1,370,000$ \\
\hline & & & & 150 & 136,832 & 1.9 & $1,027,500$ \\
\hline & & & & 3,200 & $2,919,088$ & 40.0 & $21,920,000$ \\
\hline & & & & 234 & 213,458 & 2.9 & $1,602,900$ \\
\hline & & & & 1,500 & $1,368,322$ & 18.8 & $10,275,000$ \\
\hline & & & & 2,000 & $1,824,430$ & 25.0 & $13,700,000$ \\
\hline & & & & 300 & 273,664 & 3.8 & $2,055,000$ \\
\hline & & & & 800 & 729,772 & 10.0 & $5,480,000$ \\
\hline & & & & 600 & 547,329 & 7.5 & $4,110,000$ \\
\hline & & & & 50 & 45,611 & 0.6 & 342,500 \\
\hline & & & & 2,000 & $1,824,430$ & 25.0 & $13,700,000$ \\
\hline & & & & 800 & 729,772 & 10.0 & $5,480,000$ \\
\hline & & & & 96 & 87,573 & 1.2 & 657,600 \\
\hline & & & & 2,000 & $1,824,430$ & 25.0 & $13,700,000$ \\
\hline & & & & 6,000 & $5,473,290$ & 75.0 & $41,100,000$ \\
\hline & & & & 2,000 & $1,824,430$ & 25.0 & $13,700,000$ \\
\hline \multicolumn{4}{|c|}{ Total } & \multicolumn{4}{|c|}{ Total } \\
\hline 21,800 & $19,886,286$ & 2,725 & $149,330,000$ & 52,281 & $47,691,511$ & 653.5 & $358,124,850$ \\
\hline
\end{tabular}

Note: $\mathrm{RD}=$ riksdaler, AW = average wages, TNOK2018 = value in 2018 Norwegian kroner, TAWNOK2018 = value in 2018 average wages.

4 https://www.norges-bank.no/en/Statistics/Historical-monetary-statistics/Nominal-wages-by-occupation/

5 https://www.norges-bank.no/Statistikk/Priskalkulator/ 


\subsection{Low risk aversion}

Hauge had a very diversified business portfolio. His risk aversion seems to have been low. More than 96 percent of his capital was borrowed money, in a time when one seldom borrowed more than 50 percent (Rødal \& Kiplesund, 2009, pp. 48-64). This attitude is mirrored in his signet: "Again, the kingdom of heaven is like unto a merchant man, seeking goodly pearls Who, when he had found one pearl of great price, went and sold all that he had, and bought it" (Breistein, 1953, p. 9).

Hauge sold or gave away most of his companies to followers. He appointed new leaders, whom he educated in technical and commercial skills. Thus, he created a huge network of enterprises and entrepreneurship (Dalgaard, 2011, pp. 48-66).

\section{ENTREPRENEURS BY INSPIRATION}

Since Hauge never set up a formal organization, it is not easy to define whom his followers were. However, those one is able to trace took different directions. Some took up his pioneering heritage, when some did the opposite (Dørum, 2017). We chose to follow the entrepreneurial branch.

The first generation consists of those considered Haugeans in their time from the early to the mid 1800 s. The second generation were entrepreneurs strongly influenced by Hauge's values from the last decades of the 1800 s to the late decades of the 1900 s. When the third generation are entrepreneurs during the last decades, considering themselves as influenced by Haugeanism. We call them Neo-Haugeans. These groups or generations represent innovation within industrial activity, labor welfare, popular enlightment and social engagement for a 200-year period (Seland, 2013). The purpose of looking at these groups is to map differences and similarities throughout time and to find persistent trends.

\subsection{Haugeans}

On the basis of Breistein (1953) and Rødal and Kiplesund (2009) we have been able to map 124 first generation Haugean entrepreneurs and their businesses. Many of them had rather broad portfolios. In addition to diversified portfolios, puritan modesty was a central feature among them. Many also served as lay preachers.

Table 3. Haugean entrepreneurs by industrial activity

Source: Breistein (1955, pp. 75-349)

\begin{tabular}{l|c|c}
\hline \multicolumn{1}{|c|}{$\begin{array}{c}\mathbf{N}(\mathbf{A})=\mathbf{1 2 4} \\
\mathbf{N}(\mathbf{E})=\mathbf{3 0 1}\end{array}$} & Engagement & $\begin{array}{c}\text { In percent of } \\
\text { population } \mathbf{N}(\mathbf{A})\end{array}$ \\
\hline Agriculture & 41 & 33 \\
\hline $\begin{array}{l}\text { Fisheries, fish } \\
\text { processing }\end{array}$ & 51 & 41 \\
\hline $\begin{array}{l}\text { Manufacturing, } \\
\text { Crafts }\end{array}$ & 57 & 46 \\
\hline Trade & 68 & 55 \\
\hline Property & 50 & 40 \\
\hline Publishing, printing & 17 & 14 \\
\hline Misc & 27 & 22 \\
\hline Sum & 311 & 251 \\
\hline
\end{tabular}

Note: $\mathrm{N}(\mathrm{A})=$ Population of actors, $\mathrm{N}(\mathrm{E})=$ Population of engagement.

We can find typical Haugean business approach with diversified portfolios by Arent Solem (17771857) and John Haugvaldstad (1770-1850). Solem worked his way up to become a major merchant, investor and property owner in the major city of Trondheim. He pioneered a textile factory and developed a leading fishing community at its time. He started trade and manufacturing in the capital Christiania and a shipyard outside Trondheim. Hauge's intention was that Solem and his wife should be leaders of his movement after him. However, since they didn't live up to his ideal of asceticism, it didn't happen (Rørvik, 1993, pp. 5-39).

Haugvaldstad moved to the city of Stavanger at the west coast in 1810 . Without start up capital, he gradually accumulated capital through fisheries, fish processing and exports. The capital accumulation was used for reinvestment. Thus, he built himself a portfolio including merchantry, property ownership, food processing, and textile industry and farming with new technology. Hence, he became a serious threat to the establishment (Haugvalstad, 1851, p. 22).

Another feature among the first generation of Haugeans was innovation. A typical example would be Christopher Grøndahl (1764-1864). In 1809 he moved from Kristiansand in the south to Christiania, where he became a successful book 
printer with royal privileges from 1812 . Two years later he started reporting daily news from the constitutional assembly and established a war press during the Swedish-Norwegian campaign. In 1840 , he bought the first domestic fast press and a double press driven by steam in 1854. By then he had created one of Europe's most modern printing houses (Nyquist, 1987).

Another innovator was Peter Møller (1793-1869). He received scholarship from Hauge in order to study pharmacy. In 1829, he bought a pharmacy in Christiania, which he developed to be one of the leading of its kind in Northern Europa. The same year he invested in Lilleborg textile mill, which he developed to become one of the leading oil and soap producers in Scandinavia. In 1851-1852, Møller draw on knowledge from fellow Haugeans and developed refined fish oil for medical use. Within two years he had set up three factories producing this new health product (Backe-Hansen, 1996, pp. 22-24).

One of the best examples of Haugeans with high skills in innovation is the entrepreneurship of Niels Devold (1790-1872) and his son Ole Andreas Devold (1827-1892) in Ålesund, West-Norway. They established one of the leading textile factories in Northern Europe in the mid 1850s and became pioneers within technology, product innovation and labor welfare.

Another feature with puritan entrepreneurship was the persistence of family businesses. Their companies stayed on family hands for generations. Through these generations they typically took remarkable responsibility for their local communities. Haugvalstad expressed that they were told by God's commandments to create jobs "be productive in the Earthly and still have their Mind focused on Heavenly" (Haugvaldstad, 1851, p. 22).

\subsection{Haugean descendants}

During the 19th century, puritans were assimilated into mainstream ideology and religion, which again was influenced by them. Old barriers disappeared, and it became increasingly difficult to spot them as a group. However, their ideas still influ- enced the creation of a modern nation. A significant group of entrepreneurs were also influenced by their mind-set and ethics.

Svend Foyn (1809-1894) from Tønsberg represents one of the first pioneers within this group. He was related to the movement and became the founder of modern industrial sealing and whaling through a series of technical and business innovations during the 19th century (Jacobsen, 2008).

Under Olaf Devold (1856-1933), the Devold textile factory became one of the first in Europe with telephone line, hydroelectricity and incandescent. On the island of Bømlo, south of Bergen, Martines Haldorsen (1858-1951) started production of technical equipment with his own constructed windmill as source of power. From 1903, he pioneered combustion engines for ocean going vessels. Their motors were considered some of the best in the world (Kolle, 2003).

The father of modern Norwegian furniture industry Peter Iverson Langlo (1892-1940) took part in revivalist movements in his youth. He started producing his own furniture in 1907. In 1927, it had become one of the largest in Scandinavia. From 1929 they had developed a production technique making their furniture far more cost efficient than what was the case for their competitors (Gjærde, 2000, pp. 57-160; Høidal, 2000, pp. 9-41). Jens Ekornes (1908-1976) learned how to produce furniture by Langlo. Ekornes were central in the establishment of a Norwegian furniture cluster with strong roots in puritan movements. In 1934, he established what became the largest furniture conglomerate in Scandinavia, with emphasis on product innovation and design (Høidal, 2009, pp. 11-45).

Still family enterprises ruled among the puritans. This is reflected in the furniture cluster, where a vast majority of the producers were family owned during the second generation of Haugean entrepreneurship ${ }^{6}$.

Labor welfare had still high focus under this generation. Devold and Foyn established unemployment and retirement benefits for their employees

6 Interview Mindor Hjellegjerde 14.06.2008. 
and educational scholarships for their children decades before this became common in Norway. They built hospitals, churches, mission halls and houses of high quality for their employees (Lerheim, 1952, pp. 51-79).

They were pioneers and took responsibility for their local and regional community like the first generation Haugeans. However, their portfolios were less diversified, but more specialized. They were still engaged in politics, but less than the first generation.

\subsection{Neo-Haugeans}

During the two decades, the awareness of Hauge and his contribution to the creation of the modern society has increased substantially. And during this period, a number of industrialists have come forward expressing themselves as Haugean entrepreneurs sharing his business values. These have been explicit in their connection, puritan belief and ethics. They normally run family businesses with diversified portfolios and considerable innovation focus. They are often politically active and keen contributors to their local communities.

These features can be found in some of the foremost neo-Haugeans of our time, e.g. Per Sævik (1940) and Inge Halstensen (1945), respectively, from the north western and the southwestern coast, which historically constitute two of the strongest puritan areas in the country. Both are lay preachers engaged in labor welfare, popular enlightment, private schooling and contributions to their local communities. They have served as politicians, take part in huge family business with broad portfolios and are central in some of the largest maritime clusters in Europe (Bøe, 2010, pp. 243-277)

Blom aquaculture outside Bergen can illustrate family business tradition. The founder, Andreas Blom (1923-2012), experienced a radical conversion in 1952, similar to the one Hauge had in 1796. He started as fisherman and advanced to owner of a fishing vessel, before he founded the aquaculture company engaged in salmon and trout farming in 1971, an industry largely developed on inspiration of puritan values.

\section{HAUGEAN ATTRIBUTES}

In this section, we try to pull together a different set of attributes, which are typical for Haugean companies through the generations. We will look both at motivation and how business management has been carried out.

\subsection{Stewardship as motivation}

Christian stewardship was central in Hauge's business ethics. His entrepreneurship started after his spiritual breakthrough in 1796: "we should ... consume little, and contribute as much as possible to the benefit of all. This should be our Lust, and it is the Fruit of Love. Hence, we should be good and responsible stewards, and not vast the gifts of God ...".

To do business was considered part of God's calling and duty as a Christian. We find the same kind of stewardship in many, but not all, of his followers. The second generation Haugean entrepreneur Jens Ekornes expressed this motivation very clearly (Møller, 1974, pp. 82-83): "It is nobody else than God who has created the wealth that luckily exists at Ikornnes today. My earthly task has been stewardship of this wealth. God has given me responsibility for buildings, machines and people. At the same time I know I will be held responsible for it".

Mindor Hjellegjerde, another furniture giant, from the neighboring village, explained the same kind of stewardship as "Haugean motivation for business". In consequence, it was imperative to do business to reinvest accumulated capital in productive measures to create work and values for the common good of the society. The vast majority of this Norwegian branch of puritan entrepreneurs has been modest with own consumption. At the same time, they have been involved in beneficial work $^{10}$. Quotes from leading present Haugeans

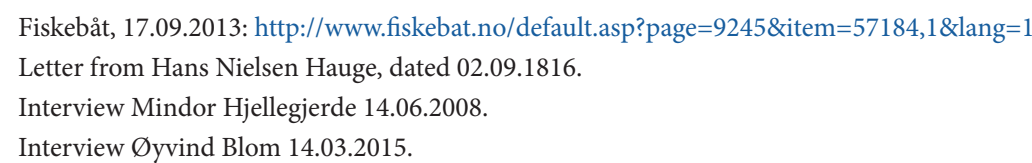


Sævik and Halstensen show this motivation exists even today: "have taken inspiration from Hauge, but even more from The Good Master Himself, that we are here to be faithful stewards of what God has given us, to the best for His Kingdom and our neighbour, not for own consumption"11.

"Hauge's ideas are taken from the Scriptures, as believers it is our duty to be good stewards for what we have been given to the benefit of the society, our fellow men and women, as well as His Kingdom It was never given to us with a purpose of personal consumption"12.

\subsection{Common attributes}

In order to map common attributes of Haugean business, we take departure in features of business management as they were described by Breistein (1953), Rødal and Kiplesund (2009). We hold this up against the information we have drawn from literature studies of second generation Haugeans and interviews with third generation Haugeans.

As can be seen in Table 4, the same set of attributes seem to have dominated all three generations of these Norwegian puritan entrepreneurs, despite they, not surprisingly, were most evident in the first generation.

These results can be illustrated in a radar diagram (Figure 4). The longer out the lines are, the more in line with the standard attributes the generation of the investigated population is. Figure $4 \mathrm{em}$ phasizes that the first generation of Haugeans applies most to the movement's attributes, when the second and third generations still have high and similar scores. For entrepreneurship and innovation along with stewardship, the scores are close to similar for the three generations. This means that these values have survived for more than 200 years in the Norwegian business community.

Table 4. Common attributes in Haugean business

\begin{tabular}{|c|c|c|c|c|c|c|c|c|c|c|}
\hline & \multirow{2}{*}{$\frac{\text { Number }(N=102)}{\text { Feature }}$} & \multicolumn{3}{|c|}{ 1st generation } & \multicolumn{3}{|c|}{ 2nd generation } & \multicolumn{3}{|c|}{ 3rd generation } \\
\hline & & Yes & UD & No & Yes & UD & No & Yes & UD & No \\
\hline 1 & Evident Christian motivation & 33 & 3 & - & 24 & 7 & - & 29 & 6 & - \\
\hline 2 & Modesty & 32 & 2 & 2 & 24 & 4 & 3 & 24 & 6 & 5 \\
\hline 3 & Family business & 33 & & 3 & 23 & 2 & 6 & 27 & 3 & 5 \\
\hline 4 & Closeness to employees & 34 & 1 & 1 & 22 & 5 & 4 & 25 & 6 & 4 \\
\hline 5 & Community responsibility & 34 & 1 & 1 & 24 & 3 & 4 & 26 & 6 & 3 \\
\hline 6 & Broad engagement for society & 28 & 2 & 4 & 21 & 4 & 6 & 23 & 5 & 7 \\
\hline 7 & Entrepreneurship and innovation & 26 & 6 & 4 & 23 & 5 & 3 & 24 & 5 & 6 \\
\hline 8 & Diversified portfolio & 28 & 2 & 6 & 20 & 3 & 8 & 23 & 4 & 8 \\
\hline 9 & Continuity & 26 & 4 & 6 & 23 & 3 & 5 & 22 & 5 & 8 \\
\hline \multirow[t]{4}{*}{10} & Stewardship & 31 & 4 & 1 & 25 & 4 & 2 & 28 & 4 & 3 \\
\hline & & - & $N=36$ & - & - & $N=31$ & - & - & $\mathrm{N}=35$ & - \\
\hline & Percent & \multicolumn{3}{|c|}{ 1st generation } & \multicolumn{3}{|c|}{ 2nd generation } & \multicolumn{3}{|c|}{ 3rd generation } \\
\hline & Feature & Yes & UD & No & Yes & UD & No & Yes & UD & No \\
\hline 1 & Evident Christian motivation & 91.7 & 8.3 & - & 77.4 & 22.6 & - & 82.9 & 17.1 & - \\
\hline 2 & Modesty & 88.9 & 5.6 & 5.6 & 77.4 & 12.9 & 9.7 & 68,6 & 17.1 & 14.3 \\
\hline 3 & Family business & 91.7 & - & 8.3 & 74.2 & 6.5 & 19.4 & 77.1 & 8.6 & 14.3 \\
\hline 4 & Closeness to employees & 94.4 & 2.8 & 2.8 & 71.0 & 16.1 & 12.9 & 71.4 & 17.1 & 11.4 \\
\hline 5 & Community responsibility & 94.4 & 2.8 & 2.8 & 77.4 & 9.7 & 12.9 & 74.3 & 17.1 & 8.6 \\
\hline 6 & Broad engagement for society & 77.8 & 5.6 & 11.1 & 67.7 & 12.9 & 19.4 & 65.7 & 14.3 & 20.0 \\
\hline 7 & Entrepreneurship and innovation & 72.2 & 16.7 & 11.1 & 74.2 & 16.1 & 9.7 & 68.6 & 14.3 & 17.1 \\
\hline 8 & Diversified portfolio & 77.8 & 5.6 & 16.7 & 64.5 & 9.7 & 25.8 & 65.7 & 11.4 & 22.9 \\
\hline 9 & Continuity & 72.2 & 11.1 & 16.7 & 74.2 & 9.7 & 16.1 & 62.9 & 14.3 & 22.9 \\
\hline 10 & Stewardship & 86.1 & 11.1 & 2.8 & 80.6 & 12.9 & 6.5 & 80.0 & 11.4 & 8.6 \\
\hline 11 & Total & 84.7 & 6.9 & 7.8 & 74.2 & 12.6 & 13.2 & 71.7 & 14.3 & 14.0 \\
\hline
\end{tabular}

11 Interview Per Sævik 03.10.2012.

12 Interview Inge Halstensen 03.10.2012. 


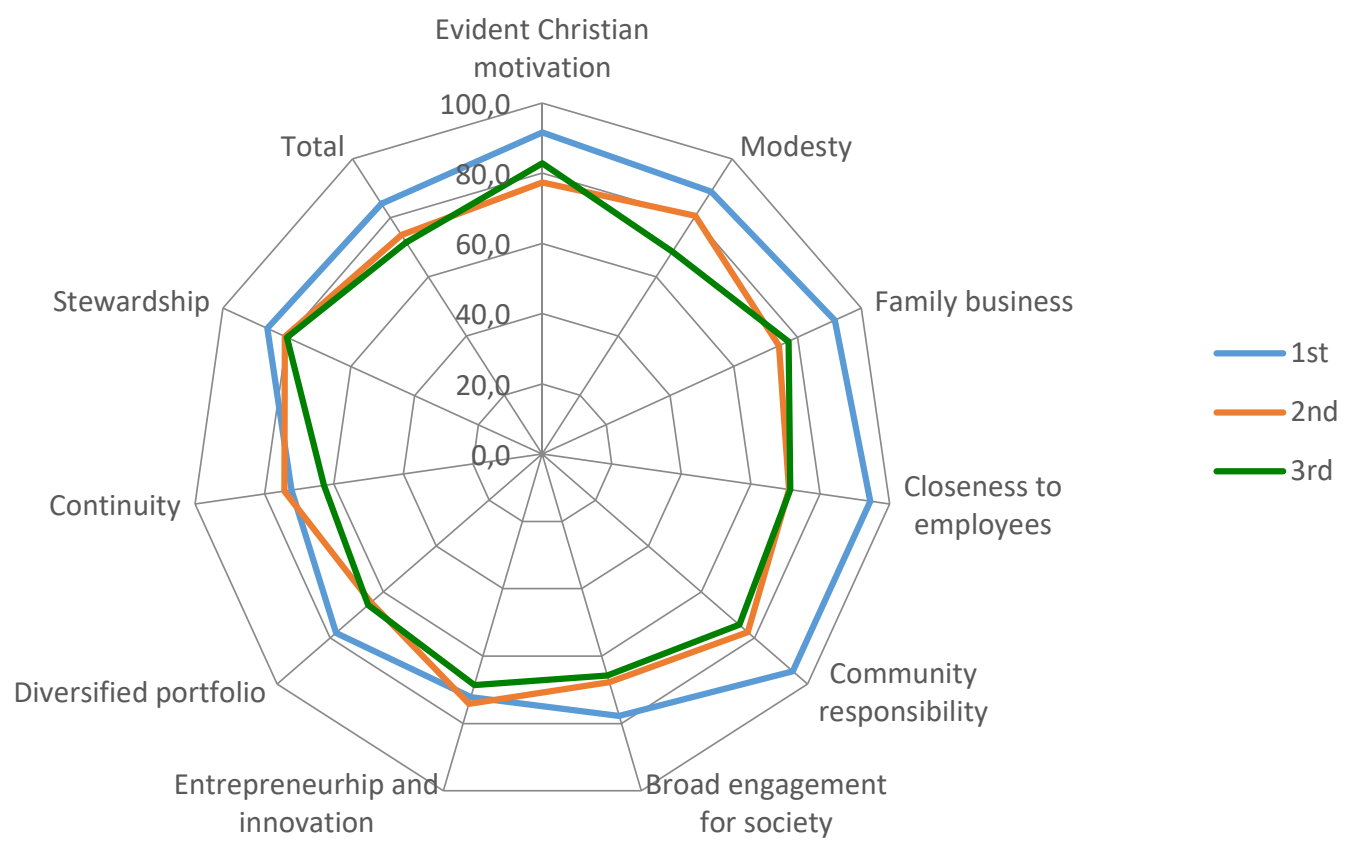

Figure 4. Radar diagram of Haugean business attributes according to generations

\section{CONCLUSION}

The paper seeks to map characteristics of puritan industrialism in terms of management and entrepreneurship. Our departure is the Solow model, which explains economic growth by three factors: labor, capital and multifactor productivity (MFP). Utilizing these factors into innovative production, entrepreneurship stands out as an important variable within MFP. By exploring different sources we find that the Norwegian puritan leader Hans Nielsen Hauge (1771-1824) took part in the establishment of around 75 business units. Additionally, he served as advisor or a resource person in the establishment of another 75 units. These represent a broad portfolio of branches. In his peak year, 1804, he must have been an important domestic investor.

The paper also sort Haugean entrepreneurship into three generations. In the first place, the Haugeans until the late 1800s. Secondly, Haugean descendants during the last decades of the 1800s until the last decades of the 1900s. Finally, Neo-Haugeans thereafter and until now.

We finally map characteristics and motivation for their business management. This is done by a study of literature, letters, interviews and quantitative utilization of existing sources and data. We conclude with ten different parameters, where puritan stewardship, Christian motivation, entrepreneurship and responsibility for the community seem to be among the most important features for their involvement. These attributes seem to have been fairly constant over time.

\section{REFERENCES}

1. Abramowitz, M. (1956). Resource and output trends in the United States since 1870. The American Economic Review, 46(2), 5-23. Retrieved from https://www.jstor.org/ stable/1910656?seq=1\#metadata_ info_tab_contents

2. Backe-Hansen, K. (1996). Apoteker Peter Møller og Møllers tran. Norges apotekerforenings tidsskrift, 94(7), 22-24.
3. Barro, R. J., \& McCleary, R. M. (2003). Religion and Economic Growth across Countries. American Sociological Review, 68(4), 760-781. Retrieved from https://www.jstor.org/ 
stable/1519761?seq=1\#metadata info_tab_contents

4. Bøe, T. (2010). Hav og Himel: historien om Per Savik og Havilakonsernet. Herøy: Havila.

5. Breistein, D. (1953). Hans Nielsen Hauge Kjøbmand i Bergen: Kristen tro og økonomisk aktivitet. Bergen: Grieg.

6. Bremer, F. J., \& Webster, T. (2005) Puritans and Puritism in Europe and America. Oxford: ABC-CLIO.

7. Dalgaard, B., \& Supphellen, M. (2011). Entrepreneurship in Norway's economic and religious nineteenth-century transformation. Scandinavian Economic History Review, 59(1), 48-66. https://doi.org/10.1080/035 85522.2011.541123

8. Delacroix, J., \& Nielsen, F. (2001). The Beloved Myth: Protestantism and the Rise of Industrial Capitalism in Nineteenth Century Europe. Social Forces, 80(2), 509-553. https://doi.org/10.1353/ sof.2001.0096

9. Denison, E. F. (1967). Why Growth Rates Differ. Postwar Experience in Nine Western Countries. Washington DC: Brookings.

10. Dørum, K., \& Sødal, H. K. (2017). Hans Nielsen Hauge fra samfunnsfiende til ikon. Oslo: Cappelen Damm.

11. Emden, P. H. (1939). Quakers in Commerce: a record of business achievement. London: Low, Marstons \& Co.

12. Fiskebåt, 17.09.2013. Retrieved from http://www.fiskebat.no/ default.asp?page $=9245 \&$ item $=571$ 84,1 \&lang $=1$

13. Gjærde, A. (Ed.) (2000). Grunnleggjaren av møbelindustrien. In 100 år 100 navn - Personer som har preget hundreåret på Nordvestlandet. Ålesund: Sunnmørsposten Forlag.

14. Grytten, O. H. (2013). The Protestant Ethic and the Spirit of Capitalism: Entrepreneurship of the Norwegian Puritan Leader Hans Nielsen Hauge. Review of European Studies, 5(1), 31-44.
15. Hauge, H. N. (1796). Betragtning over Verdens Daarlighed, forfattet i 5 Capitler og sammenskrevet $i$ Korthed af en lidet forsøgt og mindre skriftloerd Dreng Hans Nielsen Houge paa Rolfsøen i Thunøe Sogn. Christiania.

16. Haugvaldstad, J. (1851). Tilbageblik paa mit Liv. Stavanger.

17. Haukland, L. H. (2014a). Hans Nielsen Hauge: A Catalyst of literacy in Norway. Scandinavian Journal of History, 39(5), 539-559. https://doi.org/10.1080/03468755. 2014.946533

18. Haukland, L. H. (2014b). Spor av haugiansk feminisme. Kirke og Kultur, 121(4), 326-339. Retrieved from https://www.idunn.no/ kok/2014/04/spor_av_haugiansk_ feminisme

19. Heimert, A., \& Delbanco, A. (1985). The Puritans in America: A Narrative Anthology. Cambridge Massachusetts: Harvard University press.

20. Hodne, F. (1999). Verdiskapingen i manufaktur og industri i Norge 1817-1829. In O. H. Grytten (Ed.), Nordic Historical National Accounts (pp. 41-61). Bergen: Fagbokforlaget.

21. Høidal, E. (2000). Et liv i form: hedersskrift for Inge Langlo. Sykkylven: Norsk Møbelfaglig Senter.

22. Høidal, E. (2009). Ekornes fra springficer til Stressless, Ekornes 75, 1934-2009. Sykkylven: Ekornes ASA.

23. Iannaconne, L. R. (1998). Introduction to Economics of Religion. Journal of Economic Literature, 36(3), 1465-1496. Retrieved from https://econpapers. repec.org/article/aeajeclit/v_3a3 6_3ay_3a1998_3ai_3a3_3ap_ 3a1465-1495.htm

24. Interview Inge Halstensen 03.10.2012.

25. Interview Mindor Hjellegjerde 14.06.2008.

26. Interview Øyvind Blom 14.03.2015.

27. Interview Per Sævik 03.10.2012.

28. Jacobsen, A. R. (2008).
Svend Foyn: fangstpioner og nasjonsbygger. Oslo: Aschehoug.

29. Jeremy, D. (1988). Religion, Business and Wealth in Modern Britain. Routledge, London.

30. Johansen, K. E. (2017).

Kallsetikk, alkohol og økonomisk modernisering. Heimen, 54(2). Retrieved from https://idunn.no/ heimen/2017/02/_kallsetikk_alkohol_og_oekonomisk_modernisering

31. Jonassen, C. (1947). The Protestant Ethic and Spirit of Capitalism in Norway. American Sociology Review, 12(6), 676-686. https://doi.org/10.2307/2086953

32. Kaelber, L. (2005). Rational Capitalism, Traditionalism, and Adventure Capitalism: New Research on the Weber Thesis. In W. H. Swatos \& L. Kaelber (Eds.), The Protestant Ethic Turns 100: Essays on the Centenary of the Weber Thesis (pp. 139-164). London/New York: Routledge.

33. Kolle, N. (2003). Gud alene vet hvor den smed ender 100 års sammenhengende produksjon av skipsmaskineri på Rubbestadneset. Rubbestadneset: Wärtsilä. Retrieved from https://www.nb.no/nbsok/search?searchString=title: $\% 22 \mathrm{Gud} \% 20$ alene $\% 20$ vet $\% 20$ hvor\%20den $\% 20$ smed\%20ender\%20:\%20100\%20 \%C3\%A5rs\%20sammenhengende $\% 20$ produksjon $\% 20 \mathrm{av} \% 20$ skipsmaskineri\%20p\%C3\%A5\%20 Rubbestadneset $\% 22 \&$ page $=0$

34. Kullerud, D. (1996). Hans Nielsen Hauge: mannen som vekket Norge. Oslo: Aschehoug.

35. Lerheim, K. (1952). Devold fabrikker Ålesund. Ålesund: O.A. Devold AS

36. Letter from Hans Nielsen Hauge, dated 02.09.1816.

37. Letter from Hans Nielsen Hauge, dated 05.03.1815.

38. McCleary, R. M., \& Barro, R. J. (2006). Religion and Economy. Journal of Economic Perspectives, 20(2), 49-72. https://doi. org/10.1257/jep.20.2.49

39. Møller, A., \& Thorseth, L. (1974). Jens fra Ekornes. Oslo: Luther Forlag. 
40. Norborg, S. (1966). Hans Nielsen Hauge: Biografi 1804-1824. Oslo: Cappelen.

41. Norges Bank (n.d.). Nominal wages by industry 1726-2018. Retrieved from https://www. norges-bank.no/en/Statistics/ Historical-monetary-statistics/ Nominal-wages-by-industry

42. Norges Bank (n.d.). The gross domestic product for Norway. Retrieved from https://www. norges-bank.no/en/Statistics/Historical-monetary-statistics/Grossdomestic-product/ (accessed on October 30, 2009).

43. Norges Bank (n.d.). Price calculator. Retrieved from https:// www.norges-bank.no/Statistikk/ Priskalkulator/

44. Nyquist, F. P. (1987). Et moderne forlag med tradisjoner. Grøndahl \& Søn 1812-1987. Oslo: Grøndahl.
45. Ravnåsen, S. (2002). Ånd og hånd: Hans Nielsen Hauges etikk for ledelse og noringsliv. Oslo: Lutherstiftelsen.

46. Rødal, V. T., \& Kiplesund, A (2009). Hans Nielsen Hauge: Entrepreneur, Banker and Industrialist. Bergen: NHH.

47. Rørvik, S. (1993). Randi Solem - en 'frafallen' haugianer eller en foregangskvinne i kirken? Trondjhemske samlinger, 1992, 5-39.

48. Schumpeter, J. A. (1939). Business Cycles: A Theoretical, Historical and Statistical Analysis of the Capitalist Process. New York/Toronto/London: McGrawHill.

49. Seland, B. (2014). Gud og mammon: religion og næringsliv. Oslo: Cappelen Damm.
50. Sjursen, F. W. (1997). Den haugianske periode (III) 1796-ca 1850. Bergen: NLA-forlaget.

51. Solow, R. (1956). A contribution to the Theory of Economic Growth. Quarterly Journal of Economics, 70(1), 65-94. https:// doi.org/10.2307/1884513

52. Swatos, W. H., \& Kaelberg, L. (2005). The Protestant Ethic Turns 100: Essays on the Centenary of the Weber Thesis London/New York: Routledge.

53. Weber, M. (1905). The Protestant Ethic and the Spirit of Capitalism. London: Alen \& Unwin.

54. Young, C. (2009). Religion and Economic Growth in Western Europe; 1500-2000. Stanford University: Stanford. 